INTERNATIONAL HIGHER EDUCATION - NUMBER 63 SPRING 2011

Page 9-11

Westernization in the Post-Soviet World:

Risks and Benefits of the Bologna Process

Arevik Ohanyan

Arevik Ohanyan is the head of the Quality Assurance Center at Eurasia International University, Yerevan, Armenia. E-mail: arevik_ohanyan@eiu.am. She was a visiting scholar at the Center for International Higher education at Boston College in the framework of the Junior Faculty Development program.

The Bologna process is evolving as an important tool of globalization in higher education. In "The Bologna Declaration: An Explanation," prepared by the Confederation of European Union Reform rectors' conferences and the Association of European Universities, the Bologna process is described as a "common European answer to common European problems." The document highlights the value of "coordinated reforms, compatible systems and common action" to meet the challenges in higher education in all of Europe. Unquestionably, the Bologna system was created to meet the European challenges. However, a different issue is whether the Bologna process as a European response can be effective when applied to "postcommunist problems."

The intended and unintended consequences of the Bologna process on poorly consolidated and/or illiberal democracies in the postcommunist world have been treated insufficiently by policymakers and researchers. The Bologna process, as a top-down endeavor, is poorly positioned to accommodate the shared history of postcommunist states and their socialist legacies. 


\section{POOR GOVERNANCE}

Several factors complicate the successful implementation of the Bologna process in the postcommunist area. The poor governance and weak institutions in this higher education sector remains a major challenge. The successful implementation of the Bologna process assumes a democratic organizational culture characterized with bottom-up and decentralized mechanisms of administration. Transparency and accountability are assumed to be the foundation for the successful implementation of these reforms. Unfortunately, the postcommunist world inherited institutions of higher education that are highly centralized and opaque in their governance. Some stand out with autocratic and centralized management, ineffective bureaucratic practices, and massive corruption. Russian citizens pay out annually up to US\$520 million in bribes for places in higher education institutions. Even more is disbursed throughout the four-to-five years of a student's enrollment in a given institution to ensure that the student does not drop out.

This picture is much alike the scene in Armenia, another postsocialist economy, where anticorruption mechanisms and policies produced few changes-aiming at decreasing the interactions with the faculty members during the exams and at creating conditions for objective evaluation-and in some of the universities computerized tests were implemented. As the experience shows, the computer has been a poor deterrent of corruption practices during centralized entrance examinations to institutions of higher education. 


\section{INGRAINED ACADEMIC CULTURE}

The Bologna process, aimed at increasing mobility and "brain circulation," has constituted more self-centered and Eurocentric policies, but is poorly tailored to consider the developmental needs of the signatory countries beyond western Europe. This system could be better described as supporting and creating conditions for one-way mobility and one-sided development. Also, the European visa regulations support the policy of attracting and keeping the "cream of the crop" from the post-Soviet countries. The absence of mechanisms to balance brain drain with brain-circulation policies can be particularly disastrous for small economies. Indeed, "attracting talent from all over the world" into Europe is one of the major policy goals of the Bologna process, as discussed during the Convention of European Higher Education Institutions held in Salamanca in 2001.

In contrast to the highly dynamic and ambitious European educational initiatives, the post-Soviet academic culture in universities is characterized with limited academic freedom, low wages, and lack of incentives and motivation among both faculty and students. The flawed and inadequate compensation system for professors is a major contributing factor to this problem. These factors restrain innovation and individual initiatives, and by extension, they make the European higher educational area and European research area even more attractive to students and young scholars, thereby producing and sustaining brain drain from these regions into Europe. Even if students and scholars return back to their home societies after studying in Europe, they are faced with the problem of reintegration into academia and the local labor market. 


\section{ARbitrary Policies}

The centralization of educational policy and administration by the government is one of the legacies of the Soviet rule. Centralized governance undermines the much-needed local ownership and innovation of universities and, thereby, weakens the prospects of effective implementation of the Bologna reforms. The Bologna process facilitates equality between private and public universities. However, particularly in Armenia, some policies strengthen and support public universities and even undermine the private ones: exemption from mandatory military service for students serving in state universities, public financing of state universities, and mandatory accreditation of private universities but not state universities represent some examples to that end. The recent developments in Armenia, though, are promising and leave room for hoping that the market will soon be equalized by creating conditions for transparent quality-control mechanisms, as well as operating prerequisites applied both to state as well as private universities.

In short, the mismatch between the goals of the Bologna process and local realities has been problematic for effective realization of these policies so far, and the delay in appropriate reforms can result in even more of a developmental lag.

\section{CONCLUSION}

While Europe is responding proactively to increased global competition in higher education with Bologna reforms, the former-Soviet countries seem to be reacting to the European initiatives. Such reactive, as opposed to proactive, policies increasingly facilitate mobility from post-Soviet countries to European educational institutions-offering few, if any, mechanisms also to ensure the 
reverse process. Treating the Bologna system only as structural-institutional reform can weaken the educational systems in post-Soviet countries, unless the policymakers recognize that reforms at the organizational level in universities are equally important.

The gap between the Western value systems supporting the Bologna reforms and the post-Soviet legacies produces discrepancy in the goals, priorities, and initiatives. It can be asserted that no harmonization of an education system will be effective unless there is a harmony in philosophy and values underlying the decision-making processes within universities. The initiated changes and reforms would be fruitful and positive for all of the involved states in the presence of open and dynamic organizational cultures within institutions of higher education and beyond, which would contribute to much-needed innovation, adaptability, and sustained organizational learning. 